DOI: $\underline{\text { https://doi.org/10.24867/03EF04Maletic }}$

\title{
ОСОБИНЕ ТЕРМОХРОМАТСКИХ БОЈА НА ПАМЕТНИМ АМБАЛАЖНИМ МАТЕРИЈАЛИМА
}

\section{PROPERTIES OF THERMOCHROMIC INKS ON SMART PACKAGING MATERIALS}

\author{
Бојан Малетић, Драгољуб Новаковић, Стефан Ђурђевић, Факултет техничких наука, Нови Сад
}

\section{Област: ГРАФИЧКО ИНЖЕЫЕРСТВО И ДИЗАЈН}

Кратак садржај - Предмет овог рада је испитивање особина реверзибилне термохроматске боје која се примењује у изради паметне амбалаже. Циљ рада је да се испитивањем установи какав утицај имају температурне промене на оптичке особине боје која је одитампана техником сито итампе на текстилним и папирним материјалима различите повриинске масе, при чему су за штампу коришћена сита различите густине ткања.

Кључне речи: Термохроматска боја, паметна амбалажа, сито штампа

Abstract - The subject of this paper is examination of
properties of reversibile thermochromic ink which is used
in the production of smart packaging. The main goal of
the study is to determine the effect of temperature changes
on the optical properties of ink printed with screen
printing technique on textile and paper materials with
different weights, whereby different thread count meshes
were used for printing.

Key words: Thermochromic ink, smart packaging, screen printing

\section{1. УВОД}

Паметна амбалажа представља комбиновану примену специјалних материјала, науке и технологије. Према начину деловања, она може да се подели на активну и интелигентну амбалажу [1].

Паметни материјали су материјали специјално конструисани за постизање одређеног циља захваљујући способности да динамично реагују према својој околини. Заправо, они се одликују својим способностима да детектују и реагују на подражаје из окружења својим специфичним променама као што су нпр. промена боје или облика [2].

Ефект хромизма код паметних термохроматских материјала се остварује дејством топлоте која изазива промене у његовој кристалној структури, услед чега даље долази до промене оптичких својства самог материјала, што код посматрача резултује перцепцијом друге боје [3].

\section{НАПОМЕНА:}

Овај рад проистекао је из мастер рада чији ментор је био др Драгољуб Новаковић, ред. проф.
Од термохроматских материјала, најчешће се користе термохроматске боје које су доступне у форми течних кристала и у форми леуко бојила.

Према начину деловања, односно, према трајности промене боје, термохроматске боје се могу поделити на реверзибилне и иреверзибилне [4].

\section{2. ЕКСПЕРИМЕНТАЛНИ ДЕО РАДА}

Експериментални део рада обухвата израду узорака техником сито штампе на штампарском систему Screen Printing Machine S550, уз употребу плаве реверзибилне термохроматске леуко боје на бази воде, са активацијском температуром од $31{ }^{0} \mathrm{C}$.

У поступку штампе су коришћена три сита са различитим густинама ткања $(54 \mathrm{niti} / \mathrm{cm}, 120 \mathrm{niti} / \mathrm{cm}$ и $180 \mathrm{niti} / \mathrm{cm})$, а као подлоге за штампу су коришћени текстилни материјали различитог сировинског састава и површинске масе, чије карактеристике су приказане у табели 1 , као и папирни материјали површинске масе од $130 \mathrm{~g} / \mathrm{m}^{2}, 150 \mathrm{~g} / \mathrm{m}^{2}$ и $300 \mathrm{~g} / \mathrm{m}^{2}$ (у наставку рада, за представљање резултата и дискусију, папирне подлоге ће се означавати као узорак 1, узорак 2 и узорак 3 , респективно).

Након израде узорака, испитиваће се термовизијске, спектрофотометријске и колориметријске особина одштампане термохроматске боје, и то након њене активације на одговарајућој температури, дакле, у процесу њеног хлађења.

По завршетку испитивања, извршиће се обрада и анализа добијених резултата са циљем успостављања корелације између параметара у које спадају термовизијске особине, спектралне рефлексије боје, разлике боја, густина ткања сита и подлога за штампу.

Табела 1. Карактеристике текстилних материјала

\begin{tabular}{|c|c|c|c|}
\hline Текстилни & Површинска & \multicolumn{2}{|c|}{ Сировински састав } \\
\cline { 3 - 4 } материјал & маса $\left[\mathrm{g} / \mathrm{m}^{2}\right]$ & Врста & {$[\%]$} \\
\hline Узорак 1 & 208 & Памук & 100 \\
\hline Узорак 2 & 123 & Памук & $\begin{array}{c}98.6 \\
\text { Полиестар }\end{array}$ \\
\hline Узорак 3 & 81 & Памук & 100 \\
\hline \multirow{2}{*}{ Узорак 4 } & \multirow{2}{*}{120} & Памук & 14.4 \\
& & Полиестар & 85.6 \\
\hline
\end{tabular}




\section{3. РЕЗУЛТАТИ И ДИСКУСИЈА}

\section{1. Термовизијска анализа}

Циљ ове анализе јесте да се утврди какав утицај на промену температуре током времена имају различите подлоге за штампу и различите густине ткања сита.

На упоредном графичком приказу температура за текстилне узорке, представљеном на слици 1 , приметно је да максимална и минимална забележена температура није иста за све узорке.

Исто тако, приметно је да се промене температуре током времена не одвијају равномерно, већ да су највеће промене у температури забележене у прва три интервала испитивања, дакле до $30 \mathrm{~s}$, а након тога се одвијају уједначено и постепено.

Узорак 1 одштампан ситом густине ткања $120 \mathrm{niti} / \mathrm{cm}$ се одликује највећом забележеном температуром од свих осталих узорака, и износи $38.5{ }^{\circ} \mathrm{C}$, док је код узорка 2 она нешто мања и износи $35.5{ }^{\circ} \mathrm{C}$ за отисак добијен ситом $120 \mathrm{niti} / \mathrm{cm}$.

Узорак 3 карактеришу вредности температуре чија је разлика, гледајући густину ткања сита, веома слична осим за последње испитивање.

Температура од $31.4^{0} \mathrm{C}$ представља максималну забележену температуру за дати узорак. Узорак 4, посматрајући степен промена температуре током времена, своју сличност дели са узорком 2, с тим да код узорка 4 максимална забележена температура од $34.2{ }^{0} \mathrm{C}$ припада отиску који је добијен ситом густине ткања $54 \mathrm{niti} / \mathrm{cm}$.

Ако се упореде густине ткања сита, односно, забележене температуре на узорцима који су њима одштампани, уочљиво је да максималне температуре за узорке 1 и 2 одговарају отисцима добијеним ситом густине ткања $120 \mathrm{niti} / \mathrm{cm}$.

Слична ситуација је и код узорка 3 , осим за последња два испитивања, када су забележене максималне температуре припадале отиску добијеним са ситом 54 niti/cm.

Код последњег узорка у низу, узорка 4, максималне забележене температуре за сваки интервал испитивања су одговарале узорцима добијеним ситом $54 \mathrm{niti} / \mathrm{cm}$.

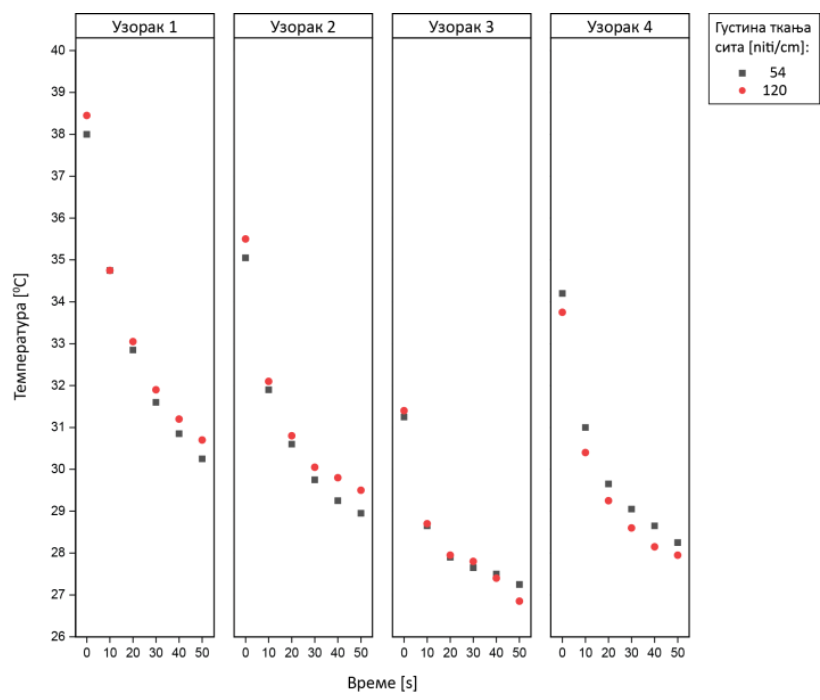

Слика 1. Температуре текстилних узорка
Са графичког приказа добијених вредности температуре за папирне материјале, представљеног на слици 2 , јасно је уочљиво да различити узорци имају различито понашање на температури, односно, да им максималне и минималне температуре нису исте, као ни степен промене температуре током времена. За приказане узорке се може видети да су се највеће промене температуре догодиле између првог и дугог, и другог и трећег испитивања, а након тога је уследио равномеран пад температуре.

Максимална забележена температура за узорак 1 је $33.2{ }^{0} \mathrm{C}$, за отисак који је добијен ситом $54 \mathrm{niti} / \mathrm{cm}$. Узорак 2 има максималну забележену температуру која износи $34.8{ }^{0} \mathrm{C}$ за отисак који је добијен ситом 54 niti/cm. Код узорака 1, 2 и 3 је такође приметно да су за свако испитивање највеће вредности температуре забележене код отисака који су добијен ситом 54 niti/cm, и да са повећањем густине ткања сита, она опада. На узорку 3 је забележена највећа вредност температуре од $39{ }^{\circ} \mathrm{C}$.

Такође, за узорак 3 се може видети да су вредности температуре за отиске који су добијени помоћу сита $120 \mathrm{niti} / \mathrm{cm}$ и $180 \mathrm{niti} / \mathrm{cm}$ веома сличне за читав циклус испитивања, као и да су у појединим интервалима испитивања те вредности биле нешто веће за узорке отиснуте са ситом $180 \mathrm{niti} / \mathrm{cm}$ од оних који су отиснути ситом $120 \mathrm{niti} / \mathrm{cm}$.

Узорци отиснути ситом густине ткања 54 niti/cm у поређењу са узорцима добијеним са преостале две густине ткања сита су забележили максималне вредности температуре за читав циклус испитивања.

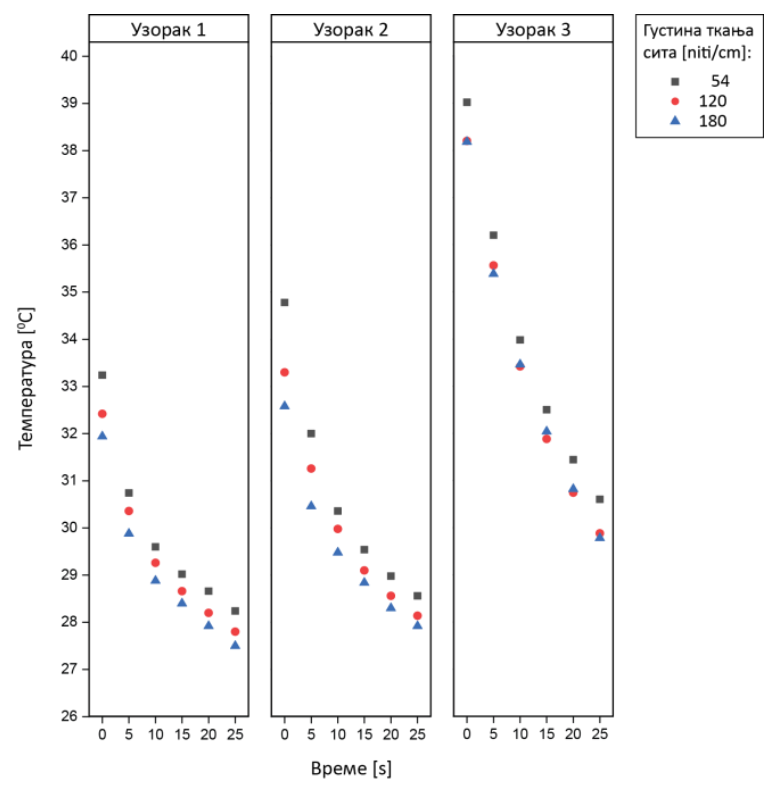

Слика 2. Температуре папирних узорка

\section{2. Спектрофотометријска анализа}

Циљ ове анализе је да се утврдити како промена температуре током времена утиче на промену степена рефлексије, при чему је у обзир узет и утицај различитих материјала за штампу и густина ткања сита.

На сликама 3 и 4 су приказане криве спектралне рефлексије текстилних узорака 3 , који у поређењу са 
осталим узорцима те групе имају значајно веће разлике у процентима рефлексије гледајући читав циклус испитивања. За узорак који је одштампан ситом густине ткања $54 \mathrm{niti} / \mathrm{cm}$ она износи $27.39 \%$, док за други узорак који је одштампан ситом густине ткања $120 \mathrm{niti} / \mathrm{cm}$ она износи 24.71 \%. Максималне забележене вредности степена рефлексије за узорак са слике 3 износи $65.49 \%$ на таласној дужини $450 \mathrm{~nm}$, а за узорак са слике 4, он износи $69.34 \%$ за таласну дужину $440 \mathrm{~nm}$.

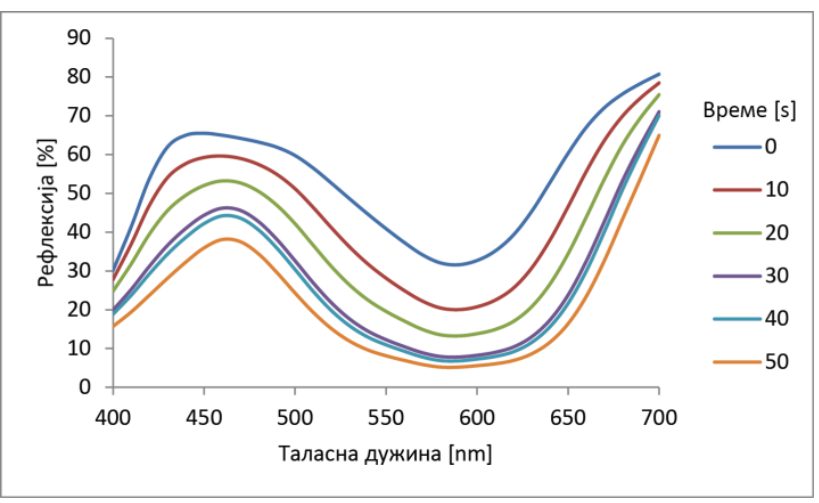

Слика 3. Криве спектралне рефлексије текстилног узорка 3, сито $54 \mathrm{niti} / \mathrm{cm}$

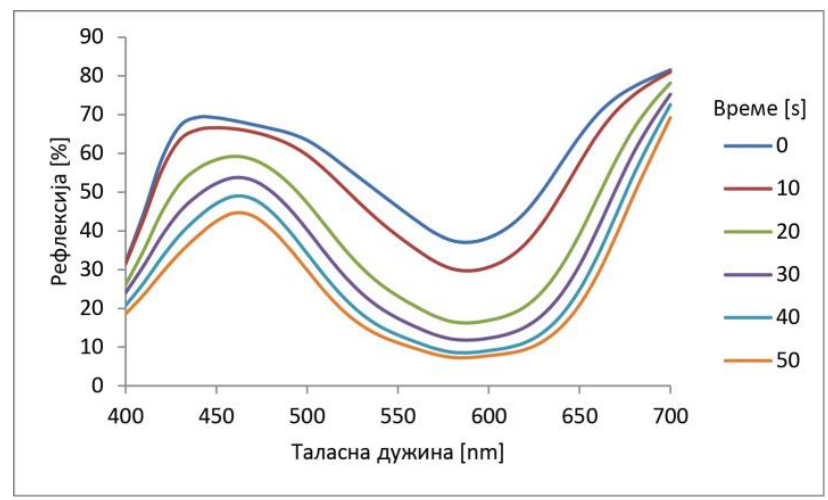

Слика 4. Криве спектралне рефлексије текстилног узорка 3, сито $120 \mathrm{niti} / \mathrm{cm}$

На сликама 5, 6 и 7 су представљене криве спектралне рефлексије за папирне узорке 1.

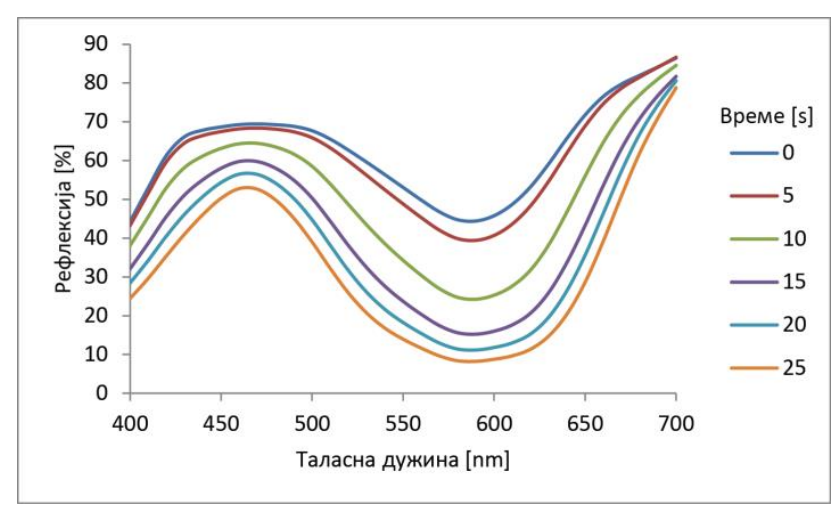

Слика 5. Криве спектралне рефлексије папирног узорка 1, сито 54 niti/cm

Максимални проценти рефлексије су забележени на таласној дужини $470 \mathrm{~nm}$ за узорке са слика 5 и 6 , и они износе $69.44 \%$ и $74.72 \%$, док је за узорак са слике 7 он забележен на $460 \mathrm{~nm}$, и износи $71.48 \%$. Разлике у проценту рефлексије које су остварене између првог и последњег испитивања износе 16.65 $\%, 17.36 \%$ и $17.09 \%$, гледајући узорке одштампане ситом од најмање ка највећој густини ткања.

Сви испитивани узорци имају приближно исти облик спектралне криве, с тим да су максимални и минимални проценат спектралне рефлексије разликују од узорка до узорка, као и њихове промене током времена тј. хлађења.

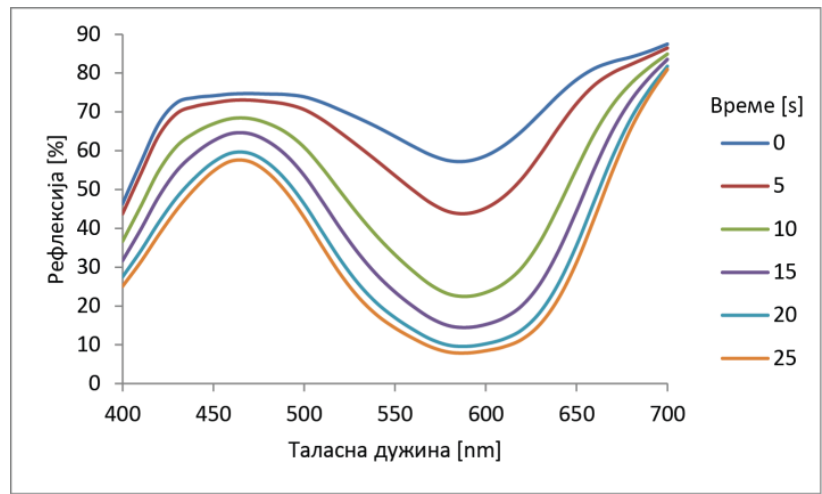

Слика 6. Криве спектралне рефлексије папирног узорка 1, сито $120 \mathrm{niti} / \mathrm{cm}$

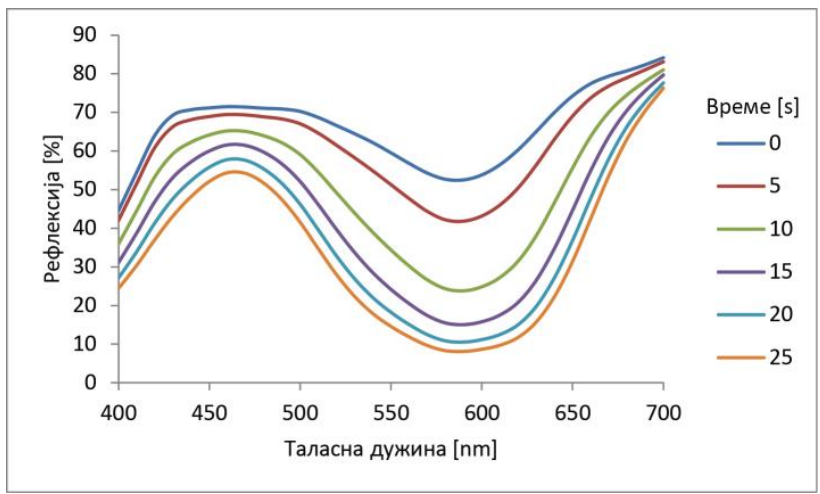

Слика 7. Криве спектралне рефлексије папирног узорка 1, сито $180 \mathrm{niti} / \mathrm{cm}$

\section{3. Колориметријска анализа}

Циљ ове анализе је да се утврди како се боја мењала током времена, и какав утицај на исту имају различите подлоге за штампу и различите густине ткања сита.

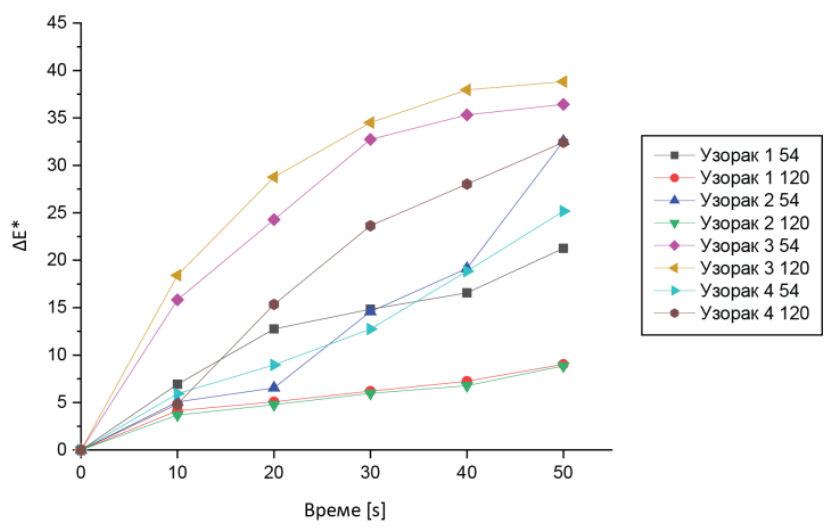

Слика 8. Разлике боја за текстилне узорке 
Посматрајући слику 8 на којој су приказане разлике боја за испитиване текстилне узорке, може се приметити колика је апсолутна разлика боја остварена у односу на вредности добијене првим испитивањем. Према томе, најмања разлика боја је остварена на узорку 2 (сито $120 \mathrm{niti} / \mathrm{cm}$ ) за који износи 8.87, и узорку 1 (сито $120 \mathrm{niti} / \mathrm{cm}$ ) за који износи 9.03. Ова два узорка су током читавог испитивања имали сличне вредности, баш као и узорци 3 (сито $54 \mathrm{niti} / \mathrm{cm}$ и $120 \mathrm{niti} / \mathrm{cm}$ ) на којима су остварене највеће разлике боја. За узорак 3 добијен ситом $54 \mathrm{niti} / \mathrm{cm}$ она износи 36.43 , док за узорак добијен ситом веће густине ткања она износи 38.83. Нешто мало испод њих се налазе узорак 2 (сито $54 \mathrm{niti} / \mathrm{cm})$ и узорак 4 (сито $120 \mathrm{niti} / \mathrm{cm})$ са укупно оствареним разликама од 32.54 и 32.43, а потом узорци 4, па 1, добијени ситом 54 niti/cm за које разлика боја износи 25.18, односно, 21.25.

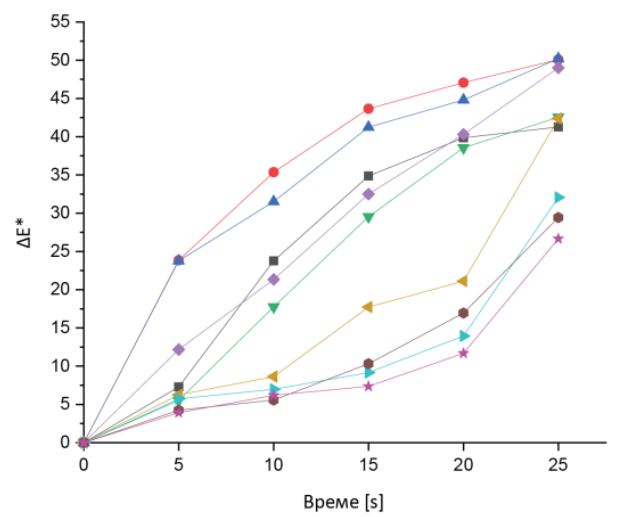

- Узорак 154 - Узорак 1120 Узорак 1180 Узорак 2120 Узорак 2180 Узорак 354 Узорак 3180

Слика 9. Разлике боја за папирне узорке

Сам крај испитивања папирних узорака је обележио узорак 2 (сито $180 \mathrm{niti} / \mathrm{cm}$ ) са променом боје у односу на предходно испитивање за 21.29, док му је укупна разлика боја, у односу на почетно испитивање, 42.40 . Узорак 2 (сито $54 \mathrm{niti} / \mathrm{cm}$ ) је остварио нешто већу укупну разлику боја која износи 42.54. Сличну апсолутну разлику боја, поред два претходно споменута узорка, је забележена за узорак 1 (сито $54 \mathrm{niti} / \mathrm{cm}$ ) за који она износи 41.27.

Најмање укупне разлике боја су добијене са узорцима 3 за које оне износе, почевши од узорка добијеног ситом највеће густине ткања, 26.65, 29.43 и 32.05. Узорак 2 одштампан ситом густине ткања $120 \mathrm{niti} / \mathrm{cm}$ је имао укупну остварену разлику боја од 49.

За овај узорак је такође карактеристично да су се његове промене током испитивања одвијале скоро константно.

Највеће апсолутне разлике боја за папирне узорке су остварене на узорцима 1 који су одштампани ситима $120 \mathrm{niti} / \mathrm{cm}$ и $180 \mathrm{niti} / \mathrm{cm}$ и за које оне износе 50.08 и 50.21 .

Са слика 8 и 9 се може видети да се различити узорци одштампани ситима различите густине ткања не понашају исто, односно, да им промена боје током времена није иста.

Исто тако се може приметити да криве појединих узорака имају сличан тренд пораста разлике боја, што нам говори да се током хлађења узорци понашају веома слично.

\section{4. ЗАКЉУЧАК}

На основу извршеног термовизијског испитивања се може закључити да узорци који су одштампани на материјалима веће површинске масе могу да апсорбују већу количину топлоте, а самим тим, на њима ће током испитивања бити забележене веће вредности температуре. Такође, код већине узорака, отисци добијени ситом мање густине ткања имају веће забележене температуре, које опадају са порастом густине ткања сита.

Обрадом и анализом резултата добијених спектрофотометријским испитивањем, може се закључити да је проценат спектралне рефлексије за узорке који су штампани ситом веће густине ткања већи од узорака који су штампани ситом мање густине ткања. Када је у питању утицај површинске масе коришћених материјала, може се донети закључак да се са смањењем површинске масе узорака и густине ткања сита, опсег рефлексије повећава.

Колориметријском анализом је утврђено да се код папирних и текстилних узорака са смањењем површинске масе разлика боја повећава. За памучне текстилне узорке веће површинске масе, већа разлика боја је остварена ситом мање густине ткања, док се код полиестарског и памучног узорка мање површинске масе, већа разлика боја добија ситом веће густине ткања.

По питању густине ткања сита код папирних узорака , највећа разлика боја се постиже комбинацијом мале површинске масе узорка и велике густине ткања сита и обратно.

\section{5. ЛИТЕРАТУРА}

[1] http://www.rocklamanna.com/blog-rocklamanna/smart-packaging-the-future-of-packaging-ishere (Pristupljeno 04.09.2018)

[2] Ferrara M., Bengisu M. (2014), ,Materials that Change Color: Smart Materials, Intelligent Design“, New York, Springer

[3] Kulčar R. (2010), „Kolorimetrijska analiza i parametri stabilnosti UV termohromnih boja - doktorska disertacija“, Zagreb, Sveučilište u Zagrebu, Grafički fakultet

[4] http://www.wrap.org.uk/sites/files/wrap/Using\%20thermochromic $\% 20$ inks $\% 20$ to $\% 20$ reduce $\% 20$ househo 1d\%20food\%20waste.pdf (Pristupljeno 16.09.2018)

Адреса аутора за контакт:

MSc Бојан Малетић

bojanmaletic93@gmail.com

Проф. др Драгољуб Новаковић

novakd@uns.ac.rs

МСц Стефан Ђурђевић

djurdjevic@uns.ac.rs

Графичко инжењерство и дизајн, Факултет техничких наука, Нови Сад 